\title{
BANKRUPTCY: EFFECT OF ACTS OF INSOLVENT ON LIFE INSURANCE EXEMPTION
}

This comment focuses upon the effect in bankruptcy of acts of the insolvent with respect to insurance on his life. Two principal questions are considered: (I) In the case of insurance exempt under state law, what are the consequences of a transfer or assignment of the policy, what are the rights of creditors with respect to premiums paid by the insured insolvent and what are the bankruptcy consequences of "loan" transactions effected during insolvency; and, (2) In the case of nonexempt insurance, may the insolvent bring his insurance within the coverage of applicable exemption statutes by change of beneficiary or relinquishment of ownership rights. These questions often turn on interpretation of state law, with an expected divergence in result. In this regard, it will be seen that state laws governing exemptions have been superimposed upon the operation of the bankruptcy scheme only with much difficulty. ${ }^{1}$

\section{General Considerations}

The rights of the trustee in bankruptcy with respect to an insurance policy in force on the life of the bankrupt are determined as of the date of the filing of the petition. ${ }^{2}$ Supreme Court decisions interpreting the bankruptcy statute have established that only nonexempt insurance having an obtainable cash surrender value at the time of bankruptcy passes to the trustee, ${ }^{3}$ and then only to the extent of that value. ${ }^{4}$ Furthermore, the bankrupt may redeem such insurance by paying over to the trustee the outstanding cash surrender value. ${ }^{5}$

Exemption of life insurance proceeds is governed by state statute. Normally, the trustee exercises no rights in insurance exempt under state law. ${ }^{6}$ State exemption statutes vary greatly in coverage and are

\footnotetext{
${ }^{1}$ See, e.g., Comment, 68 YALE L.J. 1459, 1475-82 (1959).

34 COllier, Bankruptcy $\$ 70.23$ (1942) [hereinafter cited as Collier].

${ }^{3}$ Holden v. Stratton, 198 U.S. 202 (1905).

* Burlingham v. Crouse, 228 U.S. 459 (1913).

${ }^{5}$ Bankruptcy Act $\S 70 a(5), 44$ Stat. 667 (1938), as amended, II U.S.C. § I I0 (1958). A policy may have a cash surrender value although none is provided for in the contract of insurance. For example, the loan value may be taken. Collier $\S 70.23$.

${ }^{\circ}$ Bankruptcy Act $\S 70 a(5), 44$ Stat. 667 (1938), as amended II U.S.C. $\S$ I IO (1958).
} 
impossible of classification. ${ }^{7}$ In general, these statutes limit the exemption to policies payable to spouses, children, and dependents. ${ }^{8}$ Thus, in most states, a policy payable to the estate of the insured is a general asset subject to claims of creditors. ${ }^{9}$ However, some statutes expressly provide that even these policies are exempt. ${ }^{10}$

In jurisdictions in which insurance payable to the insured's estate is nonexempt, the trustee can obtain title to insurance payable to a third party if the policy gives the insured the right unilaterally to change the beneficiary. The trustee accomplishes this by exercising the insured's right to change the beneficiary, ${ }^{11}$ making the policy payable to the insured's estate. The insurance thus becomes an asset subject to creditors' claims. $^{12}$

In summary, an insurance policy on the life of the bankrupt may be brought into the estate in bankruptcy, subject to severe limitations. In most jurisdictions, only policies payable to the insured's estate or policies subject to unilateral change of beneficiary by the insured become assets of the estate in bankruptcy. In many instances, however, the scope of exemption statutes is not well defined. Problems concerning acts of the insolvent insured with respect to his insurance are illustrative of the present confusion and divergency in the law.

\section{InSURANCE EXEMPT UNDER STATE LAW}

Cases involving exempt insurance have presented the courts with recurring questions. Does a transfer of insurance by an insolvent that wonld otherwise be avoidable as a fraudulent conveyance affect the exempt status of his insurance? May creditors of an insolvent insured

\footnotetext{
${ }^{7}$ See generally Collier $\S 6.16 ; 25$ VA. L. REv. 588, 589-90 (1939); 5 CoucH, ON INSURANCE $§ 29: 117$ (2d ed. 1960) [hereinafter cited as COUCH $2 \mathrm{~d}$ ].

${ }^{8}$ CoUch 2d § 29:124.

${ }^{\circ}$ Couch 2d $§$ 29:140 n.6.

${ }^{10}$ These jurisdictions include Florida, Iowa, Louisiana, Maine, Mississippi, New Hampshire, North Dakota, South Dakota, and Tennessee. Sec Coucr 2d \& 29:140 n.7; I Glenn, Fraudulent Conveyances and Preferences $\$ \S 182,183$ (rev. ed. 1940) [hereinafter cited as GLENN].

${ }^{11}$ Bankruptcy Act $\S 70 a(3), 64$ Stat. 26 (1950), 11 U.S.C. § 1 1 oa(3) (1958).

${ }^{12}$ See note 9 supra; Collier $\S 70.23$ n.44. Of course, this procedure would be unavailing in the states listed in note to supra. Also, the trustee's recovery is limited to the outstanding cash surrender value.

Several states have enacted legislation exempting insurance payable to spouses and dependents, even though the insurance contract allows the insured to change the beneficiary. ME. REv. STAT. ANN. ch. 60, $\S 44$ (1954); N.Y. INs. LAWs $\S 166$. In other jurisdictions the broad provisions of the subsisting statutes have been construed to uphold the exemption. Jean v. Davis, 280 Fed. 706 (8th Cir. 1922); G. P. Farmer Coal \& Supply Co. v. Albright, 90 N.J. Eq. 122, 106 Atl. 545 (1919).
} 
recover premiums paid on exempt insurance during insolvency? What are the bankruptcy consequences of "loan" transactions accomplished during insolvency? These problems remain unsettled, largely because of the multiplicity of applicable state law. Also, the courts do not agree on the effect of Bankruptcy Act provisions in this area.

\section{A. Fraudulent Conveyance of Exempt Property}

As previously noted, the trustee in bankruptcy does not acquire title to the bankrupt's exempt property. In addition, the fraudulent conveyances provision of the act expressly excludes exempt property. ${ }^{13}$ However, section 6 , as amended by the Chandler Act, ${ }^{14}$ provides that the bankrupt may not claim an exemption in fraudulently transferred property that is recovered by the trustee "under this Act for the benefit of the estate."15 The decisions and the commentators disagree over the effect of this statutory amendment on the life insurance exemption. Collier states that "a fraudulent assignment or concealment of life insurance policies with a cash surrender value, if set aside, will destroy the bankrupt's right to claim that such are exempt under $\S 6$ and $\S 70 a . " 16$ Collier does not discuss the circumstances that will allow the trustee to set aside such a transfer. Section 6 , read literally, seems to give the trustee rights that are expressly denied him in other sections of the act. ${ }^{17}$ In order to avoid such a result, section 6 has been construed ${ }^{18}$ as complementary to section $70 \mathrm{e}(\mathrm{I}),{ }^{19}$ which allows the trustee to avoid all transactions

${ }^{18}$ Bankruptcy Act $\$ 67 \mathrm{~d}(\mathrm{I})$ (a), as amended, 52 Stat. 875 , x I U.S.C. $\S 107$ (d) (I) (a) $(1958)$.

${ }_{11}{ }_{22}$ Stat. 847 (1938).

16 "§ 6, Exemptions of Bankrupts. This Act shall not affect the allowance to bankrupts of the exemptions which are prescribed by the laws of the United States or by the State laws in force at the time of the filing of the petition in the State wherein they have had their domicile for the six months immediately preceding the filing of the petition, or for a longer portion of such sixth months than in any other State: Provided, however, That no such allowance shall be made out of the property which a bankrupt transferred or concealed and which is recovered or the transfer of which is avoided under this Act for the benefit of the estate, except that, where the voided transfer was made by way of security only and the property recovered is in excess of the amount secured thereby, such allowance may be made out of such excess."

${ }^{10}$ Collier $§ 70.23$.

${ }^{17}$ Bankruptcy Act $\$ \S 67 \mathrm{~d}(\mathrm{I})(\mathrm{a}), 70 a$.

${ }^{18}$ In 68 YALE L.J. 1459,1489 ( 1959 ), it is asserted that the $\S 6$ proviso added by the Chandler Act, together with $\S 7 \mathrm{oe}(\mathrm{x})$, only serves to provide a standard rule of bankruptcy distribution in the few states where creditors may set aside conveyances of exempt property.

${ }^{10}$ Section $70 e(x)$ states: "A transfer made or suffered or obligation incurred by a debtor adjudged a bankrupt under this Act which, under any Federal or State law applicable thereto, is fraudulent as against or voidable for any other reason by any 

the insured's wife was assigned to a creditor and reassigned to the wife. Creditors of the insured contended that the policy had lost its exempt status. The applicable South Carolina fraudulent conveyance statute made every conveyance with intent to hinder, delay, or defraud void as to creditors affected thereby. The court, however, construing this statute in connection with the state exemption statute, held the proceeds exempt.

Cases applying the section 6 proviso to homestead exemptions are equally inconsistent. In Gardner v. Johnson, ${ }^{28}$ the court utilized a waiver theory in holding that a fraudulently conveyed homestead was not exempt from creditors' claims. Moreover, the court allowed the trustee to go directly against the grantee to recover the property. In a case involving similar facts, the Michigan Supreme Court, declaring that the homestead exemption is an absolute right, held that the fraudulently conveyed property of the debtor could not be subjected to creditors' claims. ${ }^{29}$ The Court of Appeals for the Tenth Circuit recently held that although a transfer of a homestead to a creditor in payment of an antecedent debt contained all the elements of a voidable preference under section 6oa(I) of the Bankruptcy Act the trustee could not recover the property from the transferee because the property in question was exempt under Oklahoma law. ${ }^{30}$ The dissent, asserting that this decision is contrary to the rule that the status and rights of bankrupt's creditors are determined as of the filing of the petition, maintained that the exemption is personal to the bankrupt and should not be allowed to a transferee. ${ }^{31}$

The failure of courts to agree on the extent to which exemptions will be honored may reflect a more basic conflict of opinion over the social purposes of bankruptcy. The section 6 proviso should bè effectuated to the extent that the bankrupt is not allowed to claim an exemption in recovered property if such property is not "absolutely" exempt but is one of several articles out of which the bankrupt is entitled to choose his exemptions. For example, if the applicable state statute exempts one automobile and the debtor owns two automobiles, the most valuable of which he fraudulently conveys to his neighbor, he should not be allowed to reap the benefit of the trustee's endeavors by substituting in

${ }^{28}$ 195 F.2d 7 17 (9th Cir. 1952), reversing In re Johnson, 97 F. Supp. 779 (S.D. Cal. I95 I).

${ }^{29}$ Cross v. Commons, 336 Mich. 665, 59 N.W.2d 4I (1953) (quoting 6 AM. JUR. Bankruptcy $\S \S$ IIII-13). Compare Branchfield v. McCulley, 23 I P.2d 77I (Ore. I95I).

${ }^{80}$ Rutledge v. Johansen, 270 F.2d 88 I (1oth Cir. 1959).

${ }^{31} \mathrm{Id}$. at 883 . 
his exemption schedule the recovered auto for the less valuable one. The applicability of section 6 to this situation is unquestioned.

In the case of property that is "absolutely" exempt, however, applicability of the proviso is not so certain. A strong argument can be made for not imposing restrictions on the debtor's right to transfer exempt property, and the frequently enunciated rule that exemption statutes should be liberally construed ${ }^{32}$ supports such a position. On the other hand, those who contend that exemptions are not a right but are "acts of legislative grace" require strict adherence to the statutory requirements. $^{33}$ Courts espousing this position seem to maintain an attitude of "caveat debtor." Other courts engage in judicial obscuration by asserting that the debtor who fraudulently conveys exempt property "waives" his right of exemption. ${ }^{34}$ The real question is: Does the debtor have a right to "fraudulently" convey property that is inherently exempt?

\section{B. Premium Payments Made During Insolvency}

The development of rules governing premium payments during insolvency lucidly portrays the increased attention paid to the social consequences of bankruptcy. If life insurance is to be accorded a preferred position within the bankruptcy scheme, the insolvent must be allowed to continue to pay premiums in order to keep in force his highlyregarded insurance protection. However, creditors' rights should not be disregarded in the process. Judicial attempts to balance these conflicting equities have produced divergent results. Early decisions held that payment of premiums during insolvency made out a prima facie case of fraud. ${ }^{35}$ As late as 1940, the weight of authority, absent statutory provision, considered premiums paid while insolvent as fraudulent and allowed creditors to recover those premiums from the proceeds of the policy. ${ }^{36}$ However, there has long existed contrary opinion. In I888, the Supreme Court, in Central Bank of Washington v. Hume, ${ }^{37}$ ruled that absent specific circumstances showing fraudulent intent the payment of premiums by an insolvent in order to keep in force insurance payable to his wife and children was not fraudulent. The obvious policy underlying this position is that a debtor, although insolvent, should be

\footnotetext{
${ }^{32}$ E.g., Schwartz v. Holzman, 69 F.2d 814 (2d Cir.), cert denied, 293 U.S. 565 (x934). See generally Couch $2 d \$ 29: 117$.

${ }^{33}$ Cf. Holden v. Stratton, $x 98$ U.S. 202 (1905).

${ }^{34}$ E.g., Gardner v. Johnson, 195 F.2d 717 (9th Cir. 1952).

${ }^{35}$ E.g., In re Goodchild, ro F. Supp. 49x (E.D.N.Y. 1935).

${ }^{36}$ GLENN $\$ \times 77$ a (citing cases).

${ }^{37}{ }^{37} 8$ U.S. $x 95$ (1888).
} 
permitted, even encouraged, to insure his life in a reasonable amount to protect his family. This is the majority view today. ${ }^{38}$

The "reasonable" amount of insurance that can be maintained during insolvency varies from state to state. Some statutes simply state that premiums paid in fraud of creditors are recoverable with interest; other jurisdictions specifically limit the amount of insurance that may be maintained or place a ceiling on allowable premium payments. ${ }^{39}$ While neither criterion is free from problems, the former "premiums paid in fraud" standard is preferable to the latter inflexible "rule of thumb." A few courts have disallowed relief to creditors despite a showing of actual fraudulent intent ${ }^{40}$ others support the contention that premiums paid during insolvency are fraudulent in law, even though the insurance is made exempt by statute. ${ }^{41}$

Even in those jurisdictions requiring proof of fraudulent intent, the quantum of proof necessary varies substantially. Generally, it must be shown that the debtor actually intended to defraud the complaining creditors. $^{42}$ The procuring of an unreasonably large amount of insurance during the period prior to bankruptcy, however, has been held to be evidence of constructive fraud. ${ }^{43}$ In contrast, one court held that a creditor seeking relief must prove fraud in the inception of the contract and must show that the beneficiary and the insurance carrier were parties to the fraud! 44

Assuming that the trustee can prove fraudulent intent, what remedies are available to him? The problems presented by an attempt to superimpose a state-created remedy designed to effectuate state law upon an entirely different federal concept are exemplified here. While at least one jurisdiction has disallowed the exemption where the premiums were fraudulently paid, ${ }^{45}$ most states allow defrauded creditors to recover premium payments, with interest, out of the proceeds of the insurance. There is no problem here if the policy matures before or during administration of the estate in bankruptcy. However, in all

${ }^{38}$ COUCH 2d \& 29:145 n. I8.

${ }^{30}$ VANCE, INSURANCE 745 nn.16-19 (2d ed. 1930).

${ }^{10}$ E.g., Greiman v. Metropolitan Life Ins. Co., 96 F.2d 823 (3d Cir.), cert. denied 305 U.S. 606 (1938); In re Silansky 21 F. Supp. 4 I (E.D. Pa. 1937).

" $\mathrm{COUCH} 2 \mathrm{~d} \S 29: 146$ n.2. The cases cited by Couch are older decisions of questionable authority today.

${ }^{22}$ COUCH 2d \$ 29:148.

${ }^{43}$ E.g., In re Newberger, I F. Supp. 685 (W.D. Okla. 1932).

“San Jacinto Bldg., Inc. v. Brown, 79 S.W.2d 164 (Tex. Civ. App. 1935).

${ }^{48}$ Lazarus v. Alphin, 185 Ark. 267, 46 S.W.2d 1104 (1932). 
other situations the trustee is in the position of having a remediless right, since the term "proceeds" almost universally has been held to include only proceeds payable at maturity. ${ }^{46}$

Here, again, conflicting equities must be balanced. The bankrupt should not be required to surrender his insurance protection in order to satisfy claims that may be insubstantial when compared with the value of the protection that would be lost. ${ }^{47}$ On the other hand, the trustee should be allowed to secure all assets that are available under law. Yet, he cannot postpone administration of the estate in bankruptcy until the death of the insured bankrupt. Indeed, such a course of action would defeat an important function of bankruptcy.

Neither of these unsatisfactory solutions is necessitated. The bankrupt should be given a choice, similar to that allowed under section $70 a(5)$. In this instance, he would be allowed to "borrow" enough on the exempt insurance to satisfy the trustee's claim based on fraudulent premium payments. If the bankrupt's equity in the policy has been exhausted, then, under the reasoning of Burlingham v. Crouse, ${ }^{48}$ the claim based on the insurance should be extinguished. The proposed rule could be enacted by Congress, thereby assuring uniform application in bankruptcy.

\section{C. "Loan" Transactions Effected During Insolvency}

$H$ takes out insurance on his life making $W$ the beneficiary. The proceeds are exempt under applicable state law. Subsequently, while insolvent, $H$ "borrows" $\$ 10,000$ on the policy. Are the proceeds of this transaction exempt from the bankrupt estate?

In considering this question, it must be kept in mind that a "loan" on

${ }^{46}$ This seems to be well-settled. In Greiman v. Metropolitan Life Ins. Co., 96 F.2d 823 (3d Cir.), cert. denied 305 U.S. 606 (1938), the Court of Appeals, following New Jersey law, held that the trustee could not recover fraudulently paid premiums out of cash surrender value, the court intimating that this policy provides a haven for fraud. In Doethlaff v. Pennsylvania Mut. Life Ins. Co., II7 F.zd 582 (6th Cir.); cert. denied $3_{1}{ }_{3}$ U.S. 579 (1941), the trustee got one step further, having obtained an order of the district court requiring the insurance company to refund premiums paid during insolvency. The Court of Appeals reversed, holding that "proceeds" did not include cash surrender value. Contra, In re Goodchild, ro F. Supp. 49 I (E.D.N.Y. 1935) (decided under superseded New York statute). See generally Coucr 2d §§ 29: I49-5 I.

"This would be especially true during the early years of a policy's life or if the insolvent were no longer insurable.

${ }_{28}^{48}$ U.S. 459 (1913). In Burlingham, the Supreme Court held that the trustee's right in nonexempt insurance was limited to the outstanding cash surrender value of the policy. 
a life insurance policy does not result in the normal debtor-creditor relationship. Rather, the amount of the loan represents a part of the insured's equity in the policy and is, in reality, an advancement. The insured borrower is not obligated to repay the amount advanced. Indeed, most life insurance "loans" are never repaid.

Glenn, answering the above hypothetical in the negative, asserts that the proceeds of a loan are not exempt. ${ }^{49}$ However, at least one case is contra. In re Basak $k^{50}$ is a classic illustration of the difficulty that courts often encounter in attempting to correlate the many facets of insurance law with bankruptcy. In this case the bankrupt "borrowed" $\$ 45,000$ on an exempt life insurance policy. The trustee petitioned the referee for an order directing the bankrupt to turn over the $\$ 45,000$ and the policies in question. The referee dismissed the petition, and the district court affirmed. The court, relying on precedent involving trustees' actions to secure the cash surrender value of exempt policies, ${ }^{51}$ held that the applicable Pensylvania statute exempted loan proceeds in the hands of the bankrupt. ${ }^{52}$ The statute speaks in terms of "net amount payable."53 Obviously, the exemption of the proceeds of the insurance at maturity should have been honored. But, why should the bankrupt be allowed to circumvent the policy behind bankruptcy by exempt "borrowing" on exempt insurance? Patently, such a result encourages conduct that tends to defeat the purpose of the insurance exemption-to provide for the family of the bankrupt after his death. Decisions like Basak vividly point up the need for careful, detailed, uniform codification of exemption law. ${ }^{54}$

\footnotetext{
${ }^{10}$ GLENN $§ 180$.

so 2 F. Supp. 278 (M.D. Pa. I935).

${ }^{51}$ The court relied on In re Phillips, 7 F. Supp. So7 (M.D. Pa. 1934), stating: "A similar question, if not the same question was before this court in Re Phillips ...." 12 F. Supp. at 279. It is true that both cases involved the question of whether insurance proceeds payable to a trustee in trust for insured's wife and children were exempt. However, Phillips did not present the question of exemption of loan proceeds paid to the bankrupt insured.

"2 Pa. STAT. ANN. tit. 40, §5I7 (1954). "The net amount payable under any policy of life insurance or under any annuity contract upon the life of any person, heretofore or hereafter made for the benefit of or assigned to the wife or children or dependent relatives of such person, shall be exempt from all claims of creditors of such person arising out of or based upon any obligation created after the passage of this act, whether or not the right to change the named beneficiary is reserved by or permitted to such person."

${ }^{83}$ Note 46 supra.

${ }^{54}$ A recent New York decision, Tanges v. Schonbrun, 196 N.Y.S.2d ${ }_{38}^{8}$ (Sup. Ct. 1959), held that under New York law (N.Y. INs. LAws $§ 166$ ) loan proceeds in the
} 
Most of the cases dealing with "loan" transactions have involved the repayment during insolvency of a prior loan. ${ }^{55}$ As in cases involving premiums paid during insolvency, assets used to repay a loan on exempt insurance are recoverable by the trustee only if fraudulent intent of the debtor in repaying the loan is proven. Several New York cases provide a convenient vehicle for tracing the development of this rule. In In re Hirsh, ${ }^{56}$ the federal district court held that repayment of "loans" and payment of advance premiums during insolvency and shortly before bankruptcy proceedings were begun was presumptively fraudulent and barred confirmation of a composition plan. The question of recovery of the loan proceeds was not before the court. In re Yaeger ${ }^{67}$ involved a similar factual situation; however, the court held that the bankrupt's repayment of the "loan" did not allow the trustee to secure the policy as an asset of the estate in bankruptcy. Both of these cases were decided under the prior New York exemption statute..$^{58}$

In Schwartz v. Seldon, ${ }^{59}$ decided under subsisting New York law, ${ }^{00}$ the court held that the bankrupt's repayment of a loan on exempt insurance could not be attacked in the absence of evidence of actual intent to defraud. ${ }^{01}$ The court disallowed the trustee's claim to the cash surrender value of the policy. ${ }^{02}$

Assuming the requisite fraudulent intent can be proven, should such a determination destroy the bankrupt's exemption? Keeping in mind that the avowed purpose of the life insurance exemption is to protect deserving beneficiaries, it would seem that every effort should be made to keep the protection intact. Viewed in this light, it becomes apparent

hands of the debtor were not protected. The court fined the bankrupt for contempt for failing to turn over the proceeds of the loan.

${ }^{5}$ To the extent that loan proceeds are nonexempt, these cases are similar to those discussed infra in which nonexempt assets are converted into exempt status on the eve on bankruptcy.

${ }_{68}$ F. Supp. 708 (S.D.N.Y. 1933).

6721 F. Supp. 324 (W.D.N.Y. I937).

${ }^{88}$ N.Y. INs. LAWS $\$ 55$ a.

${ }^{60}{ }_{153}$ F.2d 334 (2d Cir. 1945).

${ }^{\text {Bo }}$ N.Y. INS. LAWS $§$ I $66(d)$.

${ }^{82}$ On another exempt policy, the bankrupt had obtained $\$ 675.66$ from the insurance company in consideration of a reduction in the face value of the policy from $\$ 10,000$ to $\$ 5,000$. He applied this money to repayment of the loan in the other policy. The court upheld the transaction, stating that "no actual intent to defraud can be found from the mere transferring from one exempt fund to another exempt fund." 153 F.2d at 337 .

${ }_{62}$ Accord, In re Silansky, 2 I F. Supp. 4I (E.D. Pa. 1937) (repayment of loan on exempt policy with nonexempt money valid in absence of "extrinsic fraud"). 
that the ability of the insured to exhaust this protection is inconsistent with the theory of the exemption. Perhaps the Bankruptcy Act should be amended to disallow exemption of insurance on which the bankrupt has the right unilaterally to borrow. Of course, he can be denied discharge under the present law, ${ }^{63}$ but this does not satisfy creditors' immediate rights. If the exemption were denied where the bankrupt has such a right, the beneficiary, not the bankrupt, would be prejudiced. However, the bankrupt could redeem the policy under section $70 a(5)$ of the act.

In the situation in which the bankrupt repays a loan on exempt insurance in fraud of creditors, perhaps the trustee should be allowed to recover the payment out of the bankrupt's personal exemptions. Such a result, however, would require a delicate balancing of conflicting equities. Since there would be no problem if the loan situation were not allowed, the suggested federal denial of the exemption seemingly would be an equitable solution; although, implementation of such a provision would be difficult. ${ }^{64}$

\section{Conversion of NoneXempt Insurance During Insolvency}

Changes in judicial and legislative attitude toward acts of insolvents in converting nonexempt assets into exempt status reflect a more general change of philosophy with regard to exemptions. The older decisions held that a conversion of this type by an insolvent was "clearly a fraudulent conveyance."65 Other cases have held that such a transaction is presumptively fraudulent. ${ }^{66}$ Today, under the general rule, a change of beneficiary which has the effect of bringing the policy within the statutory exemption cannot be attacked as fraudulent, even though the insured was insolvent at the time. ${ }^{67}$ This is subject to the qualification that proof of actual fraud of creditors will allow relief. The cases do

\footnotetext{
${ }^{63}$ Bankruptcy Act $\S$ r4c(4), 52 Stat 850 (1938), Ir U.S.C. $\S 32 c(4)$ (1958).

ot Obviously, life insnrance contracts are not usually written in contemplation of bankruptcy. Rather, the flexible policy which allows the insured to draw on his investment during his lifetime is much more acceptable to the prospective applicant. It is doubtful whether a policy with no loan provision would be acceptable to the trade or to the insured, unless, of course, the policy is written in contemplation of bankruptcy.

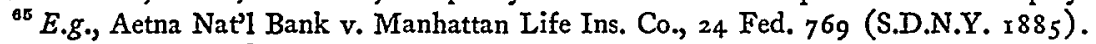
See generally GLENN $\S$ r 77 n.75.

${ }^{\circ 6}$ E.g., Catchings v. Manlove, 39 Miss. 655, 668 (r86r) ("not necessary . . . to aver that the conveyance or assignment was made with a fraudnlent intent.")

${ }^{\circ}$ Couch 2d $\$ 29: 145$.
} 
not clearly indicate the quantum of proof necessary; ${ }^{68}$ again, state law comes into play.

The effect of acquisition of exempt assets on the eve of bankruptcy has also been presented in hearings on discharge. In In re Feynman, ${ }^{\circ 0}$ the Court of Appeals for the Second Circuit affirmed the order of the district court denying a discharge on the ground that the bankrupt had fraudulently transferred an insurance policy to his wife one month prior to filing a voluntary petition in bankruptcy. Judge Learned Hand, speaking for the court, stated: "Even though . . . the policy had no surrender value, the result is the same, for at that time . . . the bankrupt could not have reclaimed it under section 70a(5)."30 In another discharge proceeding, ${ }^{71}$ however, the Court of Appeals for the Eighth Circuit held that the district court erred in denying a discharge on the ground that the bankrupt had traded non-exempt cattle for exempt hogs while insolvent and within four months of voluntary bankruptcy. The court held that the fact of the transfer alone was not sufficiently indicative of a fraudulent purpose on the part of the bankrupt. ${ }^{72}$

Judicial difference of opinion on the question of pre-bankruptcy conversions possibly reflects a more basic conflict over the status of exemptions in bankruptcy law. If exemptions are considered to be absolute rights, then it should make no difference when or in what manner the bankrupt's property is made exempt. If, on the other hand, exemptions are "acts of legislative grace" and the bankrupt must have equity's scrubbed hands before he can avail himself of the state's benevolence, then the courts should scrutinize carefully the conduct of the debtor before bankruptcy. In the light of reality and expediency, it is believed that exemptions should be absolute-and absolutely reasonable. A corollary is that they be uniform. ${ }^{73}$ In the case of life insurance, congressional reform is especially needed. Life insurance exemptions reflect sound public policy and should be given effect. However, state exemption statutes governing insurance have "grow'd" like Topsy, with

\footnotetext{
${ }^{88}$ In La Borde v. Farmers State Bank, 116 Neb. 33, 215 N.W. 559 (1927), the court held that the Nebraska statute did not exempt insurance in which debtor made his wife beneficiary two days before his death and in contemplation thereof. In Kirkpatrick v. Johnson, 197 Fed. 235 (S.E.D. Pa. 1912), the court held that a voluntary assignment by an insolvent was presumed to be fraudulent as against the trustee and allowed the trustee to recover the cash surrender value of the policy.

77 F.2d 320 (2d Cir. 1935).

${ }^{70}$ Id. at 322 .

${ }^{71}$ Forsberg v. Security State Bank, 15 F.2d 499 (8th Cir. 1926).

${ }^{72} I d$. at 502 .

${ }^{73}$ See generally Comment, 68 YALE L.J. 1459, 1514 (1959).
} 
little rhyme or reason, especially when applied-or misapplied-to bankruptcy proceedings. Congress has the power to promulgate a national schedule of insurance exemptions. ${ }^{74}$ Enactment of such legislation would greatly clarify this confused area of bankruptcy law.

${ }^{7 t}$ U.S. ConsT. art. I, $\$ 8$. 